\title{
EFFECT OF DIFFERENT INTERVAL SPEED TRAINING ON ATHLETE REACTION
}

EFEITO DE DIFERENTES INTERVALOS DE TREINAMENTO DE VELOCIDADE SOBRE A REAÇÃO DO ATLETA

EFECTO DEDIFERENTES INTERVALOS DE ENTRENAMIENTO DE VELOCIDAD EN LA REACCIÓN DEL ATLETA

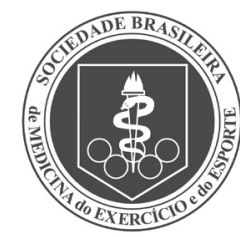

Original Article ARTIGO ORIGINAL Artículo Original

\section{Hongqiang Chen ${ }^{1}$ (D) \\ (Physical Education Professional) \\ 1. Shandong Management \\ University, Jinan, Shandong, China.}

\section{Correspondence:}

Hongqiang Chen

Jinan, Shandong, 50100, China.

HongqiangChen6@126.com

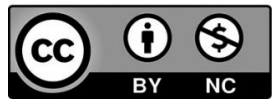

\begin{abstract}
Introduction: High-intensity Intermittent Training (HIIT) ranked first in the ACSM"2013 Global Training Methodology Survey". Objective: To explore the influence of different speed training intervals on athlete reaction speed. Methods: Sixteen male bicycle athletes were randomly divided into two groups. The two groups then completed a six-week training routine (NT). The two groups then completed a six-week training routine, started 6 weeks of Sprint Interval Training (SIT) (a total of 12 lessons), with SIT instead of Normal Training (NT) live endurance training, and another training remains unchanged. Results: After 6 weeks of NT, Pmax GXT in the CG and DG groups decreased by $0.7 \%$ and $1.7 \%$, respectively, as compared to the pre-training numbers. The difference was not statistically significant $(P>0.05)$. And after 6 weeks of SIT, Pmax GXT increased significantly $(P<0.05)$ in both experimental groups, with increases of 9.2\% and $10.2 \%$ for the $C G$ and DG groups, respectively. Conclusions: The results show that intermittent training can effectively improve the aerobic metabolism of short-haul cyclists. As the power bicycle load and the training intensity and volume of the deceleration intermittent training program increase, the more significant the changes in aerobic capacity that can result in adaptability. Level of evidence ll; Therapeutic studies - investigation of treatment results.
\end{abstract}

Keywords: Endurance Training; Substrate Cycling; Aerobic Digestion.

\section{RESUMO}

Introdução: Treinamento intermitente de alta intensidade (HIIT) classificado em primeiro lugar na ACSM "2013 Global Training Methodology Survey." Objetivo: Explorar a influência de diferentes intervalos de treinamento de velocidade na velocidade de reação do atleta. Métodos: Dezesseis ciclistas do sexo masculino foram divididos randomicamente em dois grupos. Os dois grupos completaram uma rotina de treinamento de seis semanas (NT), começaram 6 semanas de SIT (total de 12 aulas), com SIT em vez de treinamento de resistência ao vivo NT, e outro treinamento permanece inalterado. Resultados: Depois 6 semanas de NT, o GXT da Pmáx nos grupos GC e GD diminuiu 0,7\% e 1,7\%, respectivamente, em comparação com os valores pré-treinamento. A diferença não foi estatisticamente significativa $(P>0,05)$. Depois de 6 semanas de SIT, o GXT da Pmáx aumentou significativamente $(P<0,05)$ em ambos os grupos experimentais, com aumentos de 9,2\% e 10,2\% para os grupos GC e GD, respectivamente. Conclusões: Os resultados mostram que o treinamento intermitente pode melhorar efetivamente o metabolismo aeróbico de ciclistas de curta distância. À medida que a carga da bicicleta motorizada e a intensidade e volume do treinamento do programa intermitente de desaceleração aumentam, mais significativas são as mudanças da capacidade aeróbica que podem resultar em adaptabilidade. Nível de Evidência ll; Estudos terapêuticos - Investigação dos resultados do tratamento.

Descritores: Treino Aeróbico; Ciclização de substratos; Digestão aeróbia.

\section{RESUMEN}

Introducción: El entrenamiento de intervalos de alta intensidad (HIIT) ocupó el primer lugar en la ACSM "2013 Global Training Methodology Survey." Objetivo: Explorar la influencia de diferentes intervalos de entrenamiento de velocidad en la velocidad de reacción de los atletas. Métodos: Dieciséis ciclistas masculinos fueron divididos aleatoriamente en dos grupos. Ambos grupos llevaron a cabo una rutina de entrenamiento de seis semanas (NT), iniciaron 6 semanas de SIT (total 12 clases), con SIT en lugar de entrenamiento de resistencia en vivo NT, y el resto del entrenamiento permanece sin modificaciones. Resultados: Tras 6 semanas de TN, el GXT de Pmáx en los grupos GC y GD disminuyó un $0,7 \%$ y un $1,7 \%$, respectivamente, en comparación con los valores previos al entrenamiento. La diferencia no fue estadísticamente significativa $(P>0,05)$. Tras 6 semanas de SIT, el GXT de Pmáx aumentó significativamente $(P<0,05)$ en ambos grupos experimentales, con incrementos del $9,2 \%$ y del $10,2 \%$ para los grupos GC y $G D$, respectivamente. Conclusiones: Los resultados demuestran que el entrenamiento de intervalos puede mejorar eficazmente el metabolismo aeróbico de ciclistas de corta distancia. A medida que aumenta la carga de la bicicleta motorizada y la intensidad y el volumen de entrenamiento del programa de desaceleración intermitente, más significativos son los cambios en la capacidad aeróbica que pueden dar lugar a la adaptabilidad. Nivel de Evidencia Il; Estudios terapéuticos - Investigación de los resultados del tratamiento.

Descriptores: Entrenamiento Aeróbico; Ciclo del sustrato; Digestión aerobia. 


\section{INTRODUCTION}

High-intensity interval training (HIIT) ranks first in the "2013 Global Training Methods Survey" by ACSM, provide a new understanding of anaerobic training training methods and a new perspective to interpret physical training, so as to open a new chapter for the reconstruction of physical training courses and physical training methods. ' With the promotion and popularization of ball games, the ball game has achieved rapid development; With the continuous regularization and professionalization of the ball games, the requirements of the ball games are getting higher and higher. ${ }^{2}$ At the same time, the requirements for the quality of the holy ball players have also been correspondingly improved, not only requires athletes to work hard to win the game, but also requires a significant improvement in the level of competition and appreciation of the game, this requires athletes to have excellent physical fitness as a guarantee. Therefore, the physical training of the lotus ball requires a set of corresponding effective training methods. ${ }^{3}$ To study the application of high-intensity interval training (HIIT) in ball-ball sports, which is conducive to promoting the healthy development of ball-ball sports; Shorten the gap with the world's strong teams, and play a positive role in the development of volleyball.

\section{METHOD}

\section{Objects of inquiry}

16 male athletes from a provincial cycling team preparing for the "Thirteenth National Games". Among them, there are 8 master-level athletes and 8 first-level athletes. All athletes have more than 5 years of professional training experience. Participate in 3 4 national competitions every year; Good health, no major injuries that affect normal training. Athletes are randomly divided into 2 groups, 8 people in each group; $\mathbf{S}$ group carries out endurance training program (SIT); Group H implements endurance training program (HIIT); Group C is the control group and undergoes traditional endurance training (Table 1).

\section{Training program}

The experiment was carried out during the winter training of City $A$ cycling team preparing for the National Games in City B, the normal training (NT) phase, which focuses on repetitive speed endurance training on the field, and the SIT phase, which focuses on the speed-type interval training of the power car, are 12 weeks in total. The 16 athletes in the two groups first completed 6 weeks of NT, with the same weekly training content (Table 2).

\section{Test plan and indicators}

\section{GXT}

The aerobic exercise capacity is evaluated using the graded exercises tress test (GXT), tests are carried out before and after 6 weeks of NT in the first stage, and after 6 weeks of SIT in the second stage, among them, 7 people were tested in the morning and afternoon. The test sequence of the athletes was randomly arranged and recorded, and the sequence of the three tests was the same. ${ }^{4}$

\section{Test index}

Cardiopulmonary function evaluation indicators obtained through GXT include peak ventilation (VEpeak), BFpeak, peak oxygen pulse (O2pulsepeak), peak heart rate (HRpeak), 3 min heart rate recovery rate (HR-R3min). The aerobic metabolism evaluation index is composed of three parts: oxygen uptake, ventilatory threshold and blood lactic acid.

Table 1. Basic situation of athletes-list.

\begin{tabular}{c|c|c|c|c}
\hline Group & Age & Height/cm & Weight/kg & $\begin{array}{c}\text { Training } \\
\text { years/year }\end{array}$ \\
\hline $\mathrm{S}$ & $22.3 \pm 2.65$ & $178.6 \pm 4.22$ & $68.4 \pm 6.71$ & $5.73 \pm 1.35$ \\
\hline $\mathrm{H}$ & $21.8 \pm 3.41$ & $179.8 \pm 3.34$ & $69.4 \pm 4.13$ & $6.02 \pm 1.41$ \\
\hline
\end{tabular}

\section{Data processing and statistics}

Use SPSS16.0 statistical software package for statistical processing of data, all data are expressed as mean \pm standard deviation unless otherwise specified.

\section{RESULTS}

\section{Cardiopulmonary system function}

Table 3 shows the changes of the main cardiopulmonary function evaluation indexes of athletes in GXT before and after NT and SIT two-stage training. After 6 weeks of NT in Phase 1, there were no significant changes in VEpeak and BFpeak in the two experimental groups, after 6 weeks of SIT, it can be seen that the VEpeak of the CG and DG groups were slightly improved (1.6\% and $0.8 \%$ ) compared with that before NT, BFpeak also has a small increase (2.3\% and $1.6 \%)$, but they were not statistically significant.

\section{Aerobic capacity}

Changes in the main oxygen uptake evaluation indexes of athletes in GXT before and after NT and SIT two-stage training. ${ }^{5}$ After the first stage of NT, there was no significant change in VO2peak (I/min) of the two experimental groups, and after the second stage of SIT, VO2peak in the CG and DG groups increased by $8.2 \%$ and $7.8 \%$, respectively, compared with that before NT, the difference is statistically significant $(\mathrm{P}<0.05)$; R-VO2peak in CG and DG groups increased by $2.0 \%$ and $0.5 \%$ after NT, respectively ( $P>0.05)$, however, after SIT, it increased by $8.1 \%$

Table 2. NT training content and training volume in a week.

\begin{tabular}{|c|c|c|c|c|c|}
\hline & & \multicolumn{2}{|c|}{ Morning } & \multicolumn{2}{|c|}{ Afternoon } \\
\hline & $\begin{array}{l}\text { Venue } \\
\text { special }\end{array}$ & content & $\begin{array}{c}\text { Training: } \\
\text { amount of } \\
\text { training/class }\end{array}$ & Insider & $\begin{array}{l}\text { Training } \\
\text { time/class }\end{array}$ \\
\hline Monday & $\begin{array}{l}\text { explosive } \\
\text { force }\end{array}$ & $\begin{array}{l}\text { Start in place: } \\
60 \mathrm{m \times 6} ; 125 \\
\mathrm{m \times 2} ; 250 \mathrm{m \times 1}\end{array}$ & $860 m$ & $\begin{array}{l}\text { Physical } \\
\text { strength }\end{array}$ & $2 \mathrm{~h}$ \\
\hline Tuesday & $\begin{array}{c}\text { Speed } \\
\text { endurance }\end{array}$ & $\begin{array}{l}\text { Blue line: } \\
750 \text { mx4 }\end{array}$ & $3000 m$ & $\begin{array}{l}\text { Aerobic } \\
\text { recovery } \\
\text { cycling }\end{array}$ & $2 \mathrm{~h}$ \\
\hline Wednesday & $\begin{array}{l}\text { explosive } \\
\text { force }\end{array}$ & $\begin{array}{l}\text { Start in place: } \\
60 \mathrm{m \times 6} ; 125 \\
\mathrm{m \times 2} ; 250 \mathrm{~m} \times 1\end{array}$ & $860 m$ & $\begin{array}{l}\text { Aerobic } \\
\text { recovery } \\
\text { cycling }\end{array}$ & $2 \mathrm{~h}$ \\
\hline Thursday & & Rest & & $\begin{array}{l}\text { Physical } \\
\text { strength }\end{array}$ & $2 \mathrm{~h}$ \\
\hline Friday & $\begin{array}{c}\text { Speed } \\
\text { endurance }\end{array}$ & $\begin{array}{c}\text { Blue line } \\
\text { travel:750 mx4 }\end{array}$ & $3000 m$ & $\begin{array}{l}\text { Aerobic } \\
\text { recovery } \\
\text { cycling }\end{array}$ & $2 \mathrm{~h}$ \\
\hline Saturday & $\begin{array}{l}\text { Maximum } \\
\text { speed }\end{array}$ & $\begin{array}{l}\text { Marching on } \\
\text { a big slope: } \\
200 \text { mx4 }\end{array}$ & $800 m$ & $\begin{array}{l}\text { Physical } \\
\text { strength }\end{array}$ & $2 \mathrm{~h}$ \\
\hline Sunday & & Rest & & Rest & $2 \mathrm{~h}$ \\
\hline
\end{tabular}

Table 3. Changes of main indicators of cardiopulmonary function in the two experimental groups before and after the two-stage training.

\begin{tabular}{c|c|c|c|c}
\hline & Group & S0 & S1 & S2 \\
\hline VEpeak & CG & $179.5 \pm 15.9$ & $179.4 \pm 13.6$ & $182.3 \pm 12.4$ \\
\hline$(1 /$ min) & DG & $179.1 \pm 13.5$ & $178.3 \pm 10.9$ & $180.5 \pm 11.8$ \\
\hline BFpeak & CG & $64.3 \pm 8.9$ & $63.5 \pm 6.3$ & $65.8 \pm 2.1$ \\
\hline (b/min) & DG & $63.8 \pm 5.3$ & $63.9 \pm 5.2$ & $64.8 \pm 1.9$ \\
\hline O2pulsepeak & CG & $26.0 \pm 3.7$ & $25.4 \pm 3.1$ & $28.3 \pm 1.2$ \\
\hline (ml/bpm) & DG & $25.8 \pm 2.9$ & $25.7 \pm 2.1$ & $29.8 \pm 2.8$ \\
\hline HRpeak & CG & $198.3 \pm 3.7$ & $197.7 \pm 2.0$ & $198.5 \pm 3.5$ \\
\hline$(b p m)$ & DG & $199.5 \pm 4.2$ & $197.1 \pm 1.7$ & $198.8 \pm 3.4$ \\
\hline HR-R3min & CG & $28.3 \pm 2.7$ & $27.3 \pm 1.9$ & $28.0 \pm 2.9$ \\
\hline$\%$ & DG & $26.4 \pm 3.2$ & $27.0 \pm 2.0$ & $27.8 \pm 1.2$ \\
\hline
\end{tabular}


and $7.9 \%$ respectively, showing a significant improvement $(P<0.05)$; There was no significant change in the RERpeak of the three GXTs in the two experimental groups before and after the two-stage training ( $P>0.05)$, only after 6 weeks of SIT there was a slight decrease (CG decreased by $2.5 \%$, DG decreased by 1.7\%).The oxygen uptake and peak respiratory quotient in the 3 GXT before and after the two-stage training, there was no significant difference between the two experimental groups $(P>0.05)$.

\section{Aerobic capacity}

Figure 1 shows the changes in the lactic acid-load curve when the riding load is in the 2nd to 7th grades in the 3 GXT before and after the two-stage training of the CG and DG groups. ${ }^{6}$ After the first stage of NT, the lactic acid-load curve in GXT of the two experimental groups did not shift to the right, on the contrary, the BLa of the CG group increased when riding 130W, 170W, $210 \mathrm{~W}$ and 330W (increase by 12.5\%, 30.4\%, $17.2 \%$ and $10.7 \%$ respectively); After the second stage of SIT, the lactic acid-load curve in the GXT of the two experimental groups shifted significantly to the right, among them, the DG group moved more to the right in the 170W 290W area, and BLa decreased by 32\%, 30\%, 21.1\%, and $16.4 \%$ at the 4 time points, respectively.

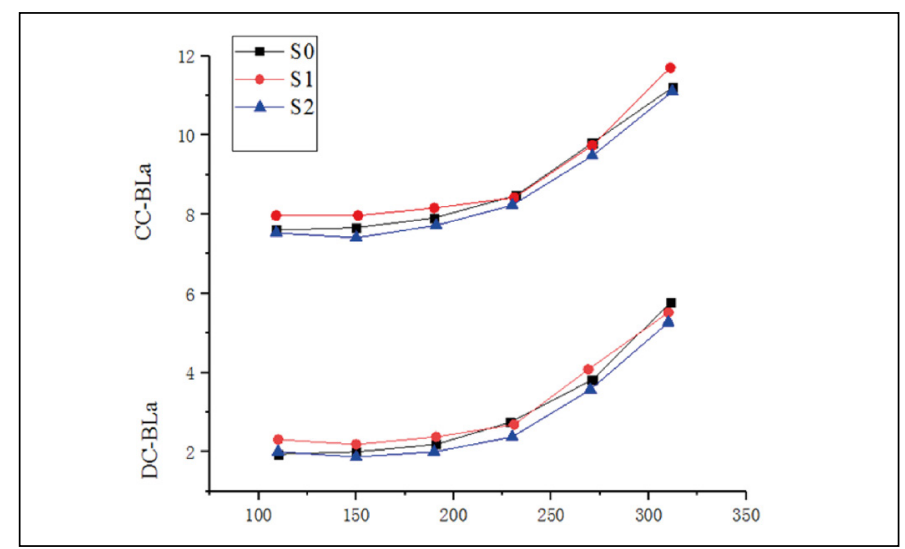

Figure 1. Comparison of the changes of lactic acid-load curve in GXT before and after two-stage training in the two experimental groups.

\section{DISCUSSION}

Research shows, completing 6 14 SIT classes in 2 weeks can effectively increase the content of skeletal muscle quiet muscle glycogen, CS and pyruvate dehydrogenase activity, the amount of glycogen decomposition and lactic acid accumulation during exercise is significantly reduced, fat oxidation rate increased significantly? In other studies that lasted up to 6 weeks, the calculated overall $\mathrm{CHO}$ and fat oxidation rates have decreased and increased respectively, the consumption of glycogen and creatine phosphate decreases during exercise at the same intensity, the decomposition of triglycerides (IMTG) increases, and SIT is a more efficient training method to improve the aerobic metabolism of skeletal muscles. ${ }^{8}$ In this study, there was no significant change in the blood lactate level immediately after the GXT test, after the second stage of SIT, the immediate blood lactate value of the two experimental groups decreased, among them, the DG group dropped significantly, indicating that the accumulation of lactic acid in the athletes decreased during exercise, it may be related to the change in the energy supply ratio of energy materials in GXT, that is, the proportion of aerobic oxidation of glycolipids increases and the proportion of anaerobic glycolysis decreases. ${ }^{9}$ Compared with the two experimental groups, the athletes trained with the SIT program of decreasing cycling times had lower immediate blood lactate levels, it suggests that a higher intensity of SIT may produce a greater degree of adaptive change. ${ }^{10}$

\section{CONCLUSION}

The 12-segment high-load power bike speed-type interval training did not have a significant impact on the function of the short-distance cyclist's respiratory system, but it improved the maximum oxygen uptake capacity; Interval training combined with endurance training can have a positive impact on the respiratory system and aerobic energy supply system of excellent road cyclists; Moreover, SIT combined with endurance training can improve the aerobic metabolism and aerobic exercise capacity of road cyclists more than HIT combined with endurance training or traditional endurance training, and the training effect is better.

The author declare no potential conflict of interest related to this article

AUTHORS' CONTRIBUTIONS: The author made significant contributions to this manuscript. Hongqiang Chen: writing and performing surgeries; data analysis and performing surgeries; article review and intellectual concept of the article.

\section{REFERENCES}

1. Li L, Li X, Xie P, Li Y, Ma L, Ding B. The effect of health-care Qigong Baduanjin combined with auricular point sticking on athletes' pre-competition anxiety: A protocol for systematic review and meta-analysis. Medicine. 2021;100(7):e24874.

2. Usuda S, Masukawa N, Leong KH, Okada K, Onuki Y. Effects of Manufacturing Process Variables on the Tablet Weight Variation of Mini-tablets Clarified by a Definitive Screening Design. Chem Pharm Bull. 2021;69(9):896-904.

3. Cowall ST, Oliver MJ, Cook LP. Effects of different levels of solar radiation and depth-varying vertical diffusion on the dynamics of a reaction-diffusion NPZ model. J Plankton Res. 2019;41(6):879-92.

4. Papasotiriou A, Athanatopoulou A, Kostinakis K. Parametric study of the masonry infills' effect on the seismic performance of $\mathrm{R} / \mathrm{C}$ frames based on the use of different damage measures. Eng Struct. 2021;241(2):112326.

5. Belkameh MM, Sedghi M, Azarfar A. The Effect of Different Levels of Dietary Magnesium on Eggshell Quality and Laying Hen's Performance. Biol Trace Elem Res. 2021;199(4):1566-73.
6. LiY, Liu Z, Wang Y, Cai L, Zheng M. Experimental study on behavior of time-related preload relaxation for bolted joints subjected to vibration in different directions. Tribol Int. 2019;142(2):106005.

7. Benjamin CL, Sekiguchi Y, Morrissey MC, Butler CR, Filep EM, Stearsn RL, et al. 364 Individual and combined effects of hydration status and ice water dousing on physiological and performance indices during intermittent exercise in the heat. Br J Sports Med. 2020;54(Suppl 1):A149.

8. Arguello J, Choi B. The Effects of Working Memory, Perceptual Speed, and Inhibition in Aggregated Search. ACM Trans Inf Syst. 2019;37(3):1-34.

9. Shao F, Wang L, Sun F, Li G, Yu L, Wang Y, et al. Study on different particulate matter retention capacities of the leaf surfaces of eight common garden plants in Hangzhou, China. Sci Total Environ. 2019;652(FEB.20):939-51.

10. Mastoraki M, PM Ferrándiz, Vardali SC, Kontodimas DC, Kotzamanis YP, Gasco L, et al. A comparative study on the effect of fish meal substitution with three different insect meals on growth, body composition and metabolism of European sea bass (Dicentrarchus labrax L.). Aquac. 2020;528(5):735511. 